\title{
Sequence Analysis of Several Ancient River Blocking Events in the Suwalong Reach of the Upper Jinsha River Based on Multidisciplinary Approaches, SE Tibetan Plateau
}

\section{Yiwei Zhang}

College of Construction Engineering, Jilin University, Changchun 130026

\section{Jianping Chen}

College of Construction Engineering, Jilin University, Changchun 130026

Qing Wang ( $\nabla$ wangqing@jlu.edu.cn )

College of Construction Engineering, Jilin University, Changchun 130026

\section{Chun Tan}

China Water Northeastern Investigation, Design and Research Co., Ltd, Changchun, Jilin 130026,

\section{Yongchao Li}

University of Chinese Academy of Sciences

\section{Shengyuan Song}

College of Construction Engineering, Jilin University, Changchun 130026

\section{Chen Cao}

College of Construction Engineering, Jilin University, Changchun 130026

\section{Feifan Gu}

College of Construction Engineering, Jilin University, Changchun 130026

\section{Research Article}

Keywords: River blocking event, Landslide dam, Multidisciplinary approaches, Dating and SBAS-InSAR

Posted Date: December 22nd, 2021

DOI: https://doi.org/10.21203/rs.3.rs-1173924/v1

License: (c) (i) This work is licensed under a Creative Commons Attribution 4.0 International License. Read Full License 


\section{Abstract}

The temporary or permanent river blocking event caused by mass movement usually occurs on steep terrain. With the increase of mountain population and land use pressure and the construction of water conservancy and hydropower projects, river blocking event has gradually attracted people's attention and understanding. The study area (Wangdalong-Gangda reach) is located in the upper reaches of the Jinsha River and the southeast edge of the Qinghai-Tibet Plateau. Affected by strong tectonic activity in the Jinsha River suture zone and the rapid uplift of the Tibetan Plateau, in the past 6000 years, there have been at least five obvious river blocking events in the reach of about $30 \mathrm{~km}$ in the study area. The number and density are very rare. Combined with the field investigation, indoor interpretation, laboratory tests, optically stimulated luminescence (OSL) dating, SBAS-InSAR and previous studies, multidisciplinary approaches are used to systematically summarize the analysis methods and further the understanding of one river blocking event and multiple river blocking events from difference perspectives. Especially in multiple river blocking events, we could get the wrong results, even the opposite conclusion if interaction is not considered. Through this study, the general method of analyzing the river blocking event and the problems that should be paid attention to in sampling are given, and relatively reliable historical results of river blocking events are obtained. This method has extensive applicability to the identification and analysis of river blocking events in other areas.

\section{Introduction}

The Qinghai-Tibet Plateau is the highest plateau in the world, and it is still in an upward trend(Chen and Li 2016; Li et al. 2020; Li et al. 2015). The upper Jinsha River is located on the southeast margin of the Qinghai-Tibet Plateau, significantly affected by tectonic uplift. There are steep slopes, deep valleys, and widely developed the mass movement(Zhan et al. 2018). When the geomorphic processes like landslides happen to cut off the river, it will lead to the formation of temporary or permanent stream blockage(Fan et al. 2019; Korup 2002) and present the greatest threat to people and property(Bao et al. 2021; Chigira et al. 2010). A recent blockage of the Jinsha River occurred on October 10, 2018, and the Baige landslide river blocking event $\left(31^{\circ} 4^{\prime} 51^{\prime \prime} \mathrm{N} ; 98^{\circ} 43^{\prime} 01^{\prime \prime} \mathrm{E}\right)$ is about $200 \mathrm{~km}$ away from the upstream of the study area. And secondary hazards could be induced when landslide dams form and fail, including dam breach, upstream inundation, and downstream flooding (Korup 2005). In addition, Jinsha River is one of the rivers with the largest water resources potential in China (Immerzeel et al. 2010), so it is the hot section in the development of water conservancy and hydropower projects. Therefore, it is of great significance to carry out geological hazard researches on this section (Sigtryggsdóttir et al. 2015; Zhang et al. 2011a).

As a complex geological and geomorphic phenomenon, especially in ancient times, the event of blocking the river contains a lot of information for the development history of Jinsha River, quaternary seismic activity, formation and evolution of catastrophic geological disasters in large valleys, and better understanding of the geological environment caused by earthquakes(Zhang et al. 2011b). In the research reach, about $26 \mathrm{~km}$, there are several large landslide bodies, six of which could be identified as river blocking event, named as Wangdalong I and II(WDL I and II), Rongcharong(RCR), Suwalong(SWL), 
Suoduoxi(SDX), Gangda (GD). It is more interested in how we can learn right the ancient information from these events.

In recent years, there have been numerous studies conducted highly concerned about dammed lakes in the Quaternary, which developed on the major rivers of the Qinghai-Tibet Plateau (Chen et al. 2013; Chen et al. 2018; Li et al. 2020; O'Connor and Costa 2004; Richardson and Reynolds 2000; Zhang et al. 2011b), and the research methods are also more quantitative and systematic. While there are still problems such as the lack of details and theoretical support due to limited information obtainable from Quaternary sediments, which makes it possible to ignore certain information about the river blocking event, and the analysis results are biased, especially in the case of multiple river blocking events in one river section.

Therefore, based on previous studies, we combined field investigation, experimental data and our own analysis methods in the paper, hoping to play a complementary role in the research of river blocking events. The goals of this study include (1) characterizing the geomorphological and sedimentological features of the ancient river-blocking events; (2) determining the formation and breaching time of ancient river-blocking events from multiple perspectives and dimensions by means of multidisciplinary method, based on the constraints from dating data, in order to restore the original appearance of historical occurrence with the greatest probability; (3) summarizing key ideas and data about analysis of an independent landslide damming of river event and interdependence landslide damming of river events; (4) summarizing of general flow and precautions of river blocking research, providing some help in research analysis, experiments, etc.

\section{Study Area}

\subsection{Regional geologic setting}

The study area is located on the upper reaches of Jinsha River in the southeastern margin of QinghaiTibet Plateau (Fig. 1 (a)). Tectonically, the structure of the study area is strong and there are many deep faults around (Fig. 1 (b)). There are two main groups of active faults in the study area: Yangla Dongzhulin Fault zone $\left(\mathrm{F}_{3}\right)$ an $\mathrm{d}$ Zeng Datong North-South fault $\left(\mathrm{F}_{4}\right)$, which are still active with the estimation of strike slip rates to be $6 \sim 7 \mathrm{~mm} / \mathrm{a}$ and vertical rates to be $2 \sim 3 \mathrm{~mm} / \mathrm{a}$ (Xu et al. 2005). The study reach belongs to arid or semi-arid climate(Chen and Li 2016), resulting in serious weathering and poor vegetation development on both sides of the bank slope. And along both sides of the valley, the exposed rocks are mainly schist, granodiorite, marble, limestone and granite (Fig. 1 (c)). These conditions lead to the development of jointed fractures in rock mass.

\subsection{Geologic Setting of each dam}

Affected by tectonic activities, there are faults near the dam body in this area, which make the surrounding rock mass more broken and joint fissures developed, and this is the main reason for the existence of landslide dams in this river section (Fig. 2). Except for GD, there are several kinds of lithology 
around the dam body, and different lithology boundaries are places with poor mechanical properties. And the inclined plate rock mass around the dam body is prone to bending and cracking. These are unfavorable factors for the stability of the river bank slope.

\section{Methodology}

Uniformitarianism also called comparative-historical method is an important paradigm in the process of geological research (Manning 2016; Windley 1993). We can deduce the conditions, processes and characteristics of ancient geological events by using the existing laws of geological action, through the geological phenomena and results left over by various geological events. 'The Present is the key to the Past' was the uniformitarian paradigm(Hutton 1788; Windley 1993) and nature is the best geological museum and laboratory, so field investigation is the premise and foundation of geological research and it is the traditional thinking method of geology. Therefore, a uniformitarian approach with the combination of modern scientific and technological is applied to improve the analysis of river blocking event.

For an ancient river blocking event, there are many nailing researches. A method called the ' trinity ' combination of residual landslide dams, upstream lacustrine sediments and downstream break-outburst sediments was proposed (Chen and Cui 2015; Li et al. 2020). In short, the fact that the river is blocked has basically reached a consensus. My main research purpose is to supplement the method and further study analysis method due to the mutual influence of these landslide damming of river events. And the method is reliably suitable for landslide dam classified by Costa and Schuster (1988).

\subsection{Analysis of an independent landslide damming of river event}

For one landslide damming of river event, some traces would be left near the location where the river was blocked. Considering a fact that there would be less key direct information left in some river blocking events, it is necessary to analyze and summarize from different dimensions and perspectives.

\subsubsection{Evidence from Remote Sensing Interpretation}

The occurrence of the river blocking event requires the joint action of two aspects. The first is the stream channel, the other is blocking dam. For the remaining Quaternary ancient river blocking event, the square is generally large. Therefore, we can search along the river to find the landslide dam body on both sides of the river on remote sensing images (Fig. 3), which is the potential evidence of blocking the river. Therefore, there will be greater changes in topography, including the change of bank slope morphology and the phenomenon of river diversion. In Google image, we can roughly circle the scope of the remaining dam block, find the source of blocking material. At the same time, we can also use DEM data for 3D modeling in GIS software such as ARCGIS to obtain some relative geometric parameters, such as the accumulation area, the accumulation length along the river, the accumulation width perpendicular to the river direction and the accumulation thickness of the dam body at the collapse. 


\subsubsection{Evidence from morphology}

After determining the approximate location of river blocking, the phenomenon of river blocking can be more accurately identified by detailed field investigation. Taking on-site photos of Gangda as an example (Fig. 4), we can see that the dam bodies on both sides of the Jinsha River have geometric continuity and a good curve can be obviously observed by abstracting it into geometry. In the photograph taken, the geometric size of the river blocking body is well identified and recognized. At this time, important information such as the maximum thickness, average thickness of the accumulation body, and the geometric position and size of the breach are recorded, which are of great significance for the verification of the inversion results of the numerical simulation.

\subsubsection{Evidences from geology}

For river blocking dam that we can find source area, geological continuity usually is maintained. That is, the lithology of the dam is similar to the lithology of the material source area. Similarly, we can look for material sources on this basis. When the lithology of the bank slopes on both sides is inconsistent, and the lithology of the residual dam on both sides is consistent, we can infer the occurrence of river blockage and determine the source of material. However, in turn, when both sides of the bank slope has the same lithology, even if the internal lithology of the residual dam is consistent, it can not be inferred that the material comes from one bank, which requires further analysis combined with remote sensing interpretation.

\subsubsection{Evidence from sedimentology}

In the study section, there are a lot of fine-grained sediments (Fig. 5). These lacustrine sediments not only directly reflect the sedimentary environment, but also reflect the hydrodynamic conditions of the transport medium. In order to determine the grain size characteristics of the lake sediments, the samples were taken from the lake sediments during the field investigation. As the lacustrine sediments particles are small, they can be all brought back for grain size analysis to obtain cumulative curve of particle size. Then we can get particle size characteristic parameters (Table 1). Firstly, according to Eli law, the diameter of the bed load moving on the riverbed is proportional to the square of the flow velocity (Eq. 1). In this study, we selected the maximum $d_{50}$ value in Table 1 as the calculation data. By the following assignment, $d=d_{50 \text { max }}=2.6 \times 10^{-5}, r_{S}=2700, r=1000, g=9.8$, we calculated $V=1.73 \times 10^{-2} \mathrm{~m} / \mathrm{s}$, which is far less than the normal velocity of Jinsha River. Secondly, according to Stokes formula, similarly, $0.026 \mathrm{~mm}$ is chosen as the calculation particle size, and the average temperature of Jinsha River is selected as $9.2^{\circ} \mathrm{C}$ (according to Batang Hydrological Station) to select the particle size calculation coefficient. The sedimentation velocity $v=8.146 \times 10^{-7} \mathrm{~m} / \mathrm{s}$ is calculated. and the setting time is about 568 days when the settling height is $40 \mathrm{~m}$. Through the above rough calculation, it is concluded that a certain thickness of fine sediment layer on the upstream of landslide body must be formed in a stable still environment where the river is blocked. Therefore, the existence of the lacustrine deposits layer can effectively reveal the river blocking event. 


$$
d=\frac{r k}{2 g f\left(r_{s}-r\right)} \cdot V^{2}
$$

where $V$ is the Velocity acting on the surface of sediment particles, $\mathrm{m} / \mathrm{s}$; $d$ is the diameter of sediment particles, $\mathrm{m} ; r_{S}$ is the density of sediment particles, $\mathrm{kg} / \mathrm{m}^{3} ; r$ is the density of water, $\mathrm{kg} / \mathrm{cm}^{3} ; \mathrm{f}$ is the coefficient of friction; $g$ is the acceleration of gravity, $9.8 \mathrm{~m} / \mathrm{s}^{2}$.

$$
V=\frac{2}{9} \cdot \frac{\left(\rho_{S}-\rho_{W}\right) g}{\eta} \cdot r^{2}
$$

2

where $v$ is the sedimentation velocity of soil particles, $\mathrm{cm} / \mathrm{s} ; r$ is the radius of soil particles, $\mathrm{cm} ; \rho_{S}$ is the density of solid particles, $\mathrm{g} / \mathrm{cm}^{3} ; \rho_{w}$ is the density of water, $\mathrm{g} / \mathrm{cm}^{3} ; \eta$ is the coefficient of dynamic viscosity of water, Pa.s; $g$ is the acceleration of gravity, $980 \mathrm{~cm} / \mathrm{s}^{2}$.

Table 1

Characteristic Parameters of Cumulative Percentage Curve of lacustrine sediments

\begin{tabular}{|lllll|}
\hline Sample & Effective size & Mean size & Control size & \multirow{2}{*}{$\boldsymbol{d}_{30} / \mathrm{mm}$} \\
\cline { 2 - 4 } & $\boldsymbol{d}_{10} / \mathrm{mm}$ & $\boldsymbol{d}_{50} / \mathrm{mm}$ & $\boldsymbol{d}_{60} / \mathrm{mm}$ & \\
\hline$S_{1}$ & 0.0050 & 0.026 & 0.032 & 0.015 \\
$\mathrm{~S}_{2}$ & 0.0029 & 0.015 & 0.019 & 0.0064 \\
\hline$S_{3}$ & 0.0090 & 0.03 & 0.036 & 0.021 \\
\hline$S_{4}$ & 0.0016 & 0.01 & 0.014 & 0.0043 \\
$S_{5}$ & 0.0043 & 0.019 & 0.026 & 0.012 \\
$S_{6}$ & 0.0027 & 0.024 & 0.029 & 0.0048 \\
$S_{7}$ & 0.0042 & 0.017 & 0.018 & 0.0087 \\
$S_{8}$ & 0.0020 & 0.009 & 0.013 & 0.0045 \\
$S_{9}$ & 0.0015 & 0.006 & 0.0088 & 0.0019 \\
\hline$S_{10}$ & 0.0023 & 0.011 & 0.014 & 0.0051 \\
\hline
\end{tabular}

Note: Location of the sample is showed in Fig. 2 as $S_{\text {number }}$ 


\subsubsection{Evidence from break-outburst sediments}

The dam break-outburst sediment is also one record of landslide dammed lake and it is also an important way to understand the dam-break process, which is usually difficult to find in an old river blocking event. According to the particle size of dam break-outburst sediments, the flood parameters at that time can be obtained by back analysis (Chen and Cui 2015; Ma et al. 2018). Besides, reasonable analysis of dam break-outburst sediments can also be made to determine the sequence of river blocking events

To summarize, for a complete landslide blocking the river event, mainly from the beginning of landslide to the end of dam break, we can mainly investigate, describe and summarize from the above five aspects. Among them, lots of lacustrine deposits is the most critical and convincing evidence for long-term existence of river blocking.

\subsection{Analysis of interdependence landslide damming of river events}

The characteristic of the study reach is that there have been many river blocking events. Therefore, more data are needed to explain whether these river blocking events interact with each other, which may be inconsistent with or even contrary to the results obtained from a single analysis of river blocking. These problems will mainly affect the judgment of river blocking time and thus affect the order of river blocking events, so more means and evidence are needed to explain the overall process of river blocking events. For example, if the WDL dammed lake formed early and lasted long, then the dating age of the lacustrine sediments is likely to indicate WDL rather than other dams upstream. Besides, considering a long time existing dammed lake, the effect of water on the genesis of other landslide dams shall be considered in numerical simulation even in such dry and rainy areas

\subsubsection{Elevation inference}

In terms of elevation, there is a rule that $\mathrm{E}_{\mathrm{dam}}$ (the elevation at stable formation of the dammed lake) $\geq$ $E_{\text {lake }}$ (the highest elevation of the dammed lake) $\geq E_{\text {lacustrine }}$ (the highest elevation of the lacustrine sediments). Since the ancient barrier lake has disappeared, we can obtain information that the present shape of the dam and the highest retention elevation of the lacustrine sediments. If the lacustrine sediments and landslide dam belong to the same river blocking event, then the highest elevation of the former cannot be higher than that of the latter. If not, the lacustrine sediments would not be formed by the dam. The principle is to rely on the geological boundary.

For $E_{d a m}$, we obtain the profile chart according to the DEM, then the original dam shape is roughly outlined reference to the form of the Baige landslide occurred in the upstream according to Feng et al. (2019). Finally, the reasonable elevation value (Fig. 6) is deduced. For $E_{\text {lacustrine, }}$ we use lacustrine sediments elevation recorded on field investigation by comparing the relatively highest point (Table 2) 
Table 2

elevation of dam crest and Maximum elevation of lacustrine deposits upstream the dam (m)

\begin{tabular}{|llllll|}
\hline dam & $\begin{array}{l}\text { Minimum } \\
\text { elevation of } \\
\text { dam crest } \\
(\mathbf{m})\end{array}$ & $\begin{array}{l}\text { Maximum elevation of } \\
\text { lacustrine deposits } \\
\text { upstream the dam }(\mathrm{m})\end{array}$ & dam & $\begin{array}{l}\text { Minimum } \\
\text { elevation of } \\
\text { dam crest } \\
(\mathbf{m})\end{array}$ & $\begin{array}{l}\text { Maximum elevation of } \\
\text { lacustrine deposits } \\
\text { upstream the dam (m) }\end{array}$ \\
\hline $\begin{array}{l}\text { WDL } \\
\text { I }\end{array}$ & 2500 & 2426 & SWL & 2394 & 2430 \\
\hline $\begin{array}{l}\text { WDL } \\
\text { II }\end{array}$ & 2463 & SDX & 2423 & 2445 \\
\hline RCR & 2444 & 2442 & GD & 2455 & 2446 \\
\hline
\end{tabular}

Based on the above results, we can analyze that WDL I, II and RCR river blocking events have a wide range of influence, and other river blocking events might have been affected. Therefore, the influence of each other must be considered in sampling analysis.

\subsubsection{Dating}

For several river blocking events, dating is a direct method to determine the sequence. Especially, multimethod dating campaigns enhance our understanding of the beginning and end of the river blocking event However, due to the limitations of objective conditions, such as the error of test methods, the lack of availability of dating samples, insufficient funds and the uncertainty of whether the obtained samples have been in the accumulation body or later mixed in, it is often necessary to analyze them from multiple aspects use different methods(Fan et al. 2021). Although more direct and high precision evidence is the ${ }^{14} \mathrm{C}$ dating age of the dam material, ${ }^{14} \mathrm{C}$ dating requires high wood charcoal samples. First, this section belongs to the dry and hot valley, and there is less vegetation on both sides of the river, so the sample collection is very difficult. Second, the source of samples can 't be guaranteed, so data may be deceptive. Therefore, the dating data of lacustrine sediments can often be used to assist the explanation. At present, the optically stimulated luminescence (OSL) dating method is widely used.

In a single river blocking event, it is reasonable to infer that the normal sequence is formed later in the upper than lower part, in other words, the bottom is older than the top. Through field investigation, there is no sequence inversion caused by tectonic movement. Besides, according to the stratigraphic relationships between the dam body and the lacustrine sediments, a relative age for the dam can be concluded.

However, for several river blocking events, due to the influence of river geomorphology (Fig. 7), the analysis of the dating results of the lacustrine sediments can be divided into the following situations:

Situations 1 , the formation of lacustrine sediments in the same river blockage with the same bottom baseline (Fig. 8(a)). In general, through the detailed investigation on the site, the relative bottom and the relative top of the lacustrine sediments are found. Through the time difference between the top and bottom, we can roughly infer the duration of the river blocking. 
Situations 2, in the same river blockage with the different bottom baseline (Fig. 8(b)). Through data processing, let the bottom at the same elevation, and then according to the situation 1 analysis.

Situations 3, in different periods of river blocking events with the same bottom baseline (Fig. 8(c), Dam II with Dam III). The age of sediments in the bottom is most likely difference. Data analysis can often form two series.

Situations 4, in different periods of river blocking events with the different bottom baseline (Fig. 8(c), Dam I with Dam II). First according to situations 2, then according to situations 3 . The specific method will be described below.

Of course, these situations only consider the general case, not all.

We first assume that several river blocking events are independent of each other, and then we make the chart (Fig. 9) according to our dating data and others (Chen et al. 2013; Chen et al. 2018). The analysis results of these data are obviously contrary to the assumption preceding part of the text that there is a negative linear correlation between years and elevation. So these data are not independent and need to be processed further. According to the results of dating data and its error, the frequency statistics is carried out with 100 years interval, and four peaks are found (Fig. 10). Under the guidance of no clear experimental purpose, the results of random sampling are related to the distribution of samples, so it can be considered that these dating data roughly represent the four river blocking events.

Therefore, we processed the data as follows:

First, the data were classified by river sections according to their locations.

Then, in each category, the classification is further carried out according to the linear relationship.

Last, the classified data are reasonably segmented combined with the results of the time-frequency histogram, and the classification results are processed into the same baseline to obtain the final results (Fig. 11).

In summary, compared with the results of ${ }^{14} \mathrm{C}$ dating data (Chen et al. 2013), the results of WDG II are very close, indicating that the analysis method is suitable. At the same time, by comparing the two results, the approximate time of river blocking in this reach can be obtained. The river blocking occurred in WDL I reach about 6300 years ago, and the duration of river blocking is about 1000 years; The river blocking occurred in WDL II reach about 1900 years ago, and the duration is about 400-840 years; The river blocking occurred in RCR reach around $1300-1400$ years ago, and the duration is about $190-370$ years; The river blocking occurred in SWL reach about 1370 ago, and the river blocking was relatively short; The river blocking occurred in SDX about 750 years ago (a time away from today) and 510 (a time close to today), and the river blocking duration was about 100-110 years; The GD river blocking time was about 900 years ago, and the river blocking duration was uncertain because of less data.

\subsubsection{Interpretation of geological phenomena}


Good analysis results should be able to reasonably explain the observed phenomenon. We explain the field investigation on this basis that the above results are correct.

First, considering landslide dam, GD and SDX residual dam body are relatively complete, the distance between the right bank dam and left bank is short, and the collapse occurs at the cross section, which indicates that the dam body exists for a short time.

Second, considering the characteristics of dam break -outburst sediments. In the upstream of SWL and SDX, the sedimentary layers under different hydrodynamic environments are found, and the maximum number of accumulation layers in SWL (Fig. 12) is more than that in SDX. This is because the formation of SWL is earlier than that of SDX and GD, so it is affected by the two river blocking events.

Third, from the point of view of lacustrine sediments, the stratification of lacustrine sediments should be more obvious and nearly horizontal in the general long-term stable water environment, while the stratification of lacustrine sediments found in SWL, SDX and GD deposits is not obvious, indicating that the water environment is not long-term stable. It was also found that the bedding of the lacustrine sediments was inclined, indicating that the sediments formed before landslides (Fig. 13). The horizontal continuous lacustrine sediments in the WDL-SWL reach up to hundreds of meters are splendidly more obvious than that in the SWL-GD reach. Therefore, according to the results of 3.2.2, the sequence of each river blocking is relatively reasonable, which is consistent with the results of field investigation.

\subsubsection{Knickpoint}

Fluvial response causing by landslide dam may theoretically influence sediment yield, channel planform, cross-section, gradient, or bed configuration(Korup et al. 2006). Among these potential response variables, we are interested in long-term fluvial response, especially in channel gradient (Fig. 14). By finding the turning point between the gentle gradient and the steep gradient, knickpoints can be recognized in the river long profile(Safran et al. 2015).

It can be seen from the Fig. 14 that the river blocking event not only generates knickpoints at the dam site, but also generates knickpoint $s$ at the upstream. Moreover, the results of the crack point analysis are basically consistent with the above dating data. The blocking age of WDL I and WDL II is long, and the change of river channel is obvious; The SWL blocking event lasted for a small time and had little effect on the river. In terms of elevation, the height fitted by the profile shape of the dam body seems to be conservative, such as the height of the WDL I may initially reach $2600 \mathrm{~m}$, and there are multiple dam breaking events.

\subsubsection{Deformation analysis}

Usually, the longer the accumulation body exists, the more tectonic activities it experiences, causing relative instability, vulnerable to erosion and gradually disappear. This explains why the longer the time the river blocking event is, the harder we find the remaining dam. 
In this paper, the surface deformation of the residual dam body was analyzed through the SARscape module of ENVI 5.3 using remote sensing image from January 2018 to December 2020. Then the average deformation rate and the response to the flood from Baige barrier lake were obtained of both the whole dam body and part of the whole area along the river (Fig. 15). By analyzing Fig. 15(a) and (b), we could draw such a conclusion that the dam bodies are in denudation state, but the denudation rate is small, which is consistent with the situation that the accumulation dam can exist for thousands of years. Comparing GD, SWL, WDL I and WDL II in the figure, the older the age, the greater the deformation rate; SDX is abnormal in Fig. 15(a) because the construction camp of Suwalong Hydropower Station is built on it, and it has been artificially transformed. While in Fig. 15(b) of the control, the part of the whole dam along the river is slightly uplifted mainly due to the uplift of the region with around $5 \mathrm{~mm} / \mathrm{yr}$ rate(Zhan et al. 2018). The RCR river section is relatively small because this reach may be a relatively "sedimentary area" in the whole study reach. As can be seen from Fig. 15(c) and (d), flood is not the main reason for the disappearance of the dam. After the flood, the dam body is in a state of accumulation rather than erosion, and the accumulation thickness of RCR is the largest in the whole river section of the study area, which may be related to the existence of a large number of continuous lacustrine sediments in the upstream of RCR; Moreover, comparing Fig. 15 (a) and (b), it can be drawn that the erosion rate along the river section of RCR is lower than the whole erosion rate, because the material on the upper part of the dam body is eroded and stripped from the original position and then deposited in the lower part of the dam body along the river.

If the above deformation can only explain the result of a period of time, the landform of the accumulation dam body is the result of long-term evolution. Through the rough measurement of two relatively distant points on both sides of the residual dam body by Google map, the erosion section length perpendicular to the river of WDL I is about $1100 \mathrm{~m}$, WDL II is about $500 \mathrm{~m}, \mathrm{RCR}$ is about $350 \mathrm{~m}, \mathrm{SDX}$ is about $190 \mathrm{~m}$, and $\mathrm{GD}$ is about $200 \mathrm{~m}$, these data are positively correlated with the ages of the accumulation dams.

In conclusion, the evidence of deformation analysis can indirectly prove that the age of the accumulation dam body is reliable.

\section{Results And Discussions}

The geological environment of the research area breeds a wide range of mass movement, which creates good conditions for the occurrence of the river blocking event. For an ancient river blocking event, whether dammed lakes persist for short times or long times(Costa and Schuster 1991), there will always be some traces near the river block. Based on the previous research, our team summarize the five important aspects of the field investigation of the river blocking event, and provide some theoretical basis and supplement. Among these evidences, the dam body on both sides is the most intuitive evidence of ancient river blocking event, because it is one of the necessary conditions for the formation of the river blocking; and the wide range of lacustrine sediments accumulated behind the dam is a convincing and abundant evidence (because its existence often indicates longer duration of dammed lake). For example, based on lacustrine sediments located in the same profile, we could roughly predict the age and duration 
of the river blocking event by calculating the difference between the age of the top layer and the bottom layer; then we could obtain the average deposition rate by dividing the difference by the thickness of the lacustrine sediments, which is related to the sediment content, fine particle composition and climate; the mineral composition of the sediment; and chemical composition can reveal the source of material and sedimentary environment, etc. In addition, because of its widespread existence and fine-grained sediment with low cementation strength, it makes sampling convenient. Compared with the ${ }^{14} \mathrm{C}$ dating (samples need higher requirements and are not easy to obtain, sometimes even unable to find the appropriate test sample, the samples used for OSL dating of lacustrine sediments are easily found and obtained, which could increase efficiency and prevention of accidental errors. However, when multiple river blocking events occur in a river reach interact with each other, if the sample is not carefully distinguished from which river blocking event, the analysis results from OSL dating will be seriously affected, for example, the analysis unable to continue or even sometimes get wrong conclusion. In this paper, a feasible method for analyzing several river blocking events is proposed. Then, combined with the ${ }^{14} \mathrm{C}$ dating results and the geological phenomena of field investigation, the relative reasonable sequence of river blocking is obtained, and the age of some river blocking events that previous researchers did not give clear results have also been identified. An accurate activity history is of great significance not only for the further study of the tectonic activity and sedimentary climate at that time, but also for the numerical simulation of dam-break and accurate back analysis of the event of landslide blocking river occurrence.

At the same time, our team finds that the error of OSL dating by using lacustrine sediments is within the acceptable range, but the following proposals must be paid attention to: 1). Before sampling, the experimental plan must be made and the samples should be collected purposefully; 2 ). Light should be avoided when sampling, and timely experiments should be conducted after sampling; Otherwise, the sample needs to be sealed, avoided light, stored at room temperature; 3 ). The determination of moisture content of samples is a very important error factor, which is not only the current moisture content, but also the average moisture content of samples in the historical process; 4). Under money and time permitted conditions, parallel samples should be collected around the sample and a profile sequence should be collected for dating in order to reduce accidental errors and improve the accuracy of the results.

Although the research method and research ideas are quite complete, the research is negligent because of the complicated geological environment of the reach, the urgent time in the investigation, the inaccessibility of some positions to carry out the field investigation, and the inability to take samples due to the high sampling location. Therefore, the results presented in this paper are one of the development process of river blocking with a greater probability. More discussion is welcome from the following researchers. Finally, in order to make the relevant investigation more detailed and efficient, we makes a systematic summary based on our team and previous studies, and puts forward the following complete Investigation and analysis flow chart (Fig. 16), so that the relevant investigation can be more scientific and comprehensive, and fully reflect the relevant geological and geomorphic information.

\section{Conclusions}


This paper presented a widely applicable method for investigating river blocking bodies and studying multiple river blocking processes in the same reach. Through this method, the relatively reliable river blocking sequence evolution history of Wangdalong-Gangda reach was scientifically and effectively restored. The results of elevation and dating analysis showed that the river blocking occurred in WDL I reach about 6300 years ago, WDL II reach about 1900 years ago, RCR reach around $1300-1400$ years ago, SWL reach about 1370 ago, SDX reach about 750 years ago (a time away from today) and 510 (a time close to today), and GD river blocking time was about 900 years ago. The formation of these barrier lake led to the decrease of river dynamics and river deposition effect, which may be an important reason for the inhibition of river channel incision and directly affect the evolution of local landscape(Li et al. 2021). From this perspective, the above results were also well verified by geological phenomena, knickpoints and accumulation deformation. This study is of great significance because it shows that the integrated method can provide a reasonable explanation for the evolution of the history of the river closure in this section and provide a basis for further in-depth study and reference for similar cases.

\section{Declarations}

\section{Acknowledgements}

This research was financially supported by the Key Project of NSFC-Yunnan Joint Fund (Grant no. U1702241), the National Natural Science Foundation of China囚Grant No.42177139『and the National Key Research and Development Plan (Grant No. 2018YFC1505301). The authors would like to thank Yuchao $\mathrm{Li}$, Zhihai Li, Zhaoxi Wang, Jiejie Shen et al. for their contributions to the collection of field data and data processing, and the editor and anonymous reviewers for their comments and suggestions which helped a lot in making this paper better.

Conflict of interest The authors declare no competing interests.

\section{References}

1. Bao, Y., Sun, X., zhou, X., Zhang, Y.Liu, Y. 2021. Some numerical approaches for landslide river blocking: introduction, simulation, and discussion. Landslides, doi: 10.1007/s10346-021-01725-2.

2. Chen, J.Cui, Z. 2015. Discovery of Outburst Deposits Induced by the Xuelongnang PaleolandslideDammed Lake in the Upper Jinsha River,China and Its Environmental and Hazard Significance. Acta Sedimentologica Sinica, 33, 275-284, doi: 10.14027/j.cnki.cjxb.2015.02.007.

3. Chen, J., Dai, F., Lv, T.Cui, Z. 2013. Holocene landslide-dammed lake deposits in the Upper Jinsha River, SE Tibetan Plateau and their ages. Quaternary International, 298, 107-113, doi: 10.1016/j.quaint.2012.09.018.

4. Chen, J.Li, H. 2016. Genetic mechanism and disasters features of complicated structural rock mass along the rapidly uplift section at the upstream of Jinsha River. Journal of Jilin University. Earth Science Edition, 46, 1153-1167, doi: 10.13278/j.cnki.jjuese.201604202. 
5. Chen, J., Zhou, W., Cui, Z., Li, W., Wu, S.Ma, J. 2018. Formation process of a large paleolandslidedammed lake at Xuelongnang in the upper Jinsha River, SE Tibetan Plateau: constraints from OSL and 14C dating. Landslides, 15, 2399-2412, doi: 10.1007/s10346-018-1056-3.

6. Chigira, M., Wu, X., Inokuchi, T.Wang, G. 2010. Landslides induced by the 2008 Wenchuan earthquake, Sichuan, China. Geomorphology, 118, 225-238, doi: 10.1016/j.geomorph.2010.01.003.

7. Costa, J.E.Schuster, R.L. 1988. The formation and failure of natural dams. Geological Society of America Bulletin, 100, 1054-1068, doi: 10.1130/0016-7606(1988)100<1054:Tfafon>2.3.Co;2.

8. Costa, J.E.Schuster, R.L. 1991. Documented historical landslide dams from around the world. OpenFile Report.

9. Fan, X., Dufresne, A., Whiteley, J., Yunus, A.P., Subramanian, S.S., Okeke, C.A.U., Pánek, T., Hermanns, R.L., Ming, P., Strom, A., Havenith, H.-B., Dunning, S., Wang, G.Tacconi Stefanelli, C. 2021. Recent technological and methodological advances for the investigation of landslide dams. Earth-Science Reviews, 218, doi: 10.1016/j.earscirev.2021.103646.

10. Fan, X., Scaringi, G., Korup, O., West, A.J., Westen, C.J., Tanyas, H., Hovius, N., Hales, T.C., Jibson, R.W., Allstadt, K.E., Zhang, L., Evans, S.G., Xu, C., Li, G., Pei, X., Xu, Q.Huang, R. 2019. Earthquake-Induced Chains of Geologic Hazards: Patterns, Mechanisms, and Impacts. Reviews of Geophysics, 57.

11. Feng, W., Zhang, G., Bai, H., Zhou, Y., Xu, Q.Zheng, G. 2019. A Preliminary Analysis Of The Formation Mechanism And Development Tendency Of The Huge Baige Landslide In Jinsha River On October 11,2018. Journal of Engineering Geology, 27, 415-426, doi: 10.13544/j.cnki.jeg.2018-392.

12. Hutton, J. 1788. X. Theory of the Earth; or an Investigation of the Laws observable in the Composition, Dissolution, and Restoration of Land upon the Globe. Transactions of the Royal Society of Edinburgh, 1, 209-304, doi: 10.1017/s0080456800029227.

13. Immerzeel, W.W., van Beek, L.P.Bierkens, M.F. 2010. Climate change will affect the Asian water towers. Science, 328, 1382-1385, doi: 10.1126/science.1183188.

14. Korup, 0. 2002. Recent research on landslide dams - a literature review with special attention to New Zealand. Progress in Physical Geography, 26, 206-235, doi: 10.1191/0309133302pp333ra.

15. Korup, O. 2005. Geomorphic hazard assessment of landslide dams in South Westland, New Zealand: fundamental problems and approaches. Geomorphology, 66, 167-188, doi:

10.1016/j.geomorph.2004.09.013.

16. Korup, O., Strom, A.L.Weidinger, J.T. 2006. Fluvial response to large rock-slope failures: Examples from the Himalayas, the Tien Shan, and the Southern Alps in New Zealand. Geomorphology, 78, 321, doi: 10.1016/j.geomorph.2006.01.020.

17. Li, Y., Chen, J., Zhou, F., Song, S., Zhang, Y., Gu, F.Cao, C. 2020. Identification of ancient river-blocking events and analysis of the mechanisms for the formation of landslide dams in the Suwalong section of the upper Jinsha River, SE Tibetan Plateau. Geomorphology, 368, doi:

10.1016/j.geomorph.2020.107351.

18. Li, Y., Wang, C., Dai, J., Xu, G., Hou, Y.Li, X. 2015. Propagation of the deformation and growth of the Tibetan-Himalayan orogen: A review. Earth-Science Reviews, 143, 36-61, doi: 
10.1016/j.earscirev.2015.01.001.

19. Li, Z., Wang, Q., Zhou, F., Li, Y., Han, X., Mehmood, Q., Cao, C., Gu, F., Han, M.Chen, J. 2021. Integrating an interferometric synthetic aperture radar technique and numerical simulation to investigate the Tongmai old deposit along the Sichuan-Tibet Railway. Geomorphology, 377, doi: 10.1016/j.geomorph.2020.107586.

20. Ma, J., Chen, J., Cui, Z., Zhou, W., Liu, C., Guo, P.Shi, Q. 2018. Sedimentary evidence of outburst deposits induced by the Diexi paleolandslide-dammed lake of the upper Minjiang River in China. Quaternary International, 464, 460-481, doi: 10.1016/j.quaint.2017.09.022.

21. Manning, P.M. 2016. Charles Lyell's Geological Imagination. Literature Compass, 13, 646-654, doi: 10.1111/lic3.12352.

22. O'Connor, J.E.Costa, J.E. 2004. The world's largest floods, past and present: Their causes and magnitudes. doi: 10.3133/cir1254.

23. Richardson, S.D.Reynolds, J.M. 2000. An overview of glacial hazards in the Himalayas. Quaternary International, 65-66, 31-47, doi: 10.1016/s1040-6182(99)00035-x.

24. Safran, E.B., O'Connor, J.E., Ely, L.L., House, P.K., Grant, G., Harrity, K., Croall, K.Jones, E. 2015. Plugs or flood-makers? The unstable landslide dams of eastern Oregon. Geomorphology, 248, 237-251, doi: 10.1016/j.geomorph.2015.06.040.

25. Sigtryggsdóttir, F.G., Snæbjörnsson, J.T., Grande, L.Sigbjörnsson, R. 2015. Methodology for geohazard assessment for hydropower projects. Natural Hazards, 79, 1299-1331, doi: 10.1007/s11069-015-1906-4.

26. Windley, B.F. 1993. Uniformitarianism today: plate tectonics is the key to the past. Journal of the Geological Society, 150, 7-19, doi: 10.1144/gsjgs.150.1.0007.

27. Xu, X.-w., Zhang, P.-z., Wen, X.-Z., Qin, Z.-I., Chen, G.-h.Zhu, A.-I. 2005. Features Of Active Tectonics And Recurrence Behaviors Of Strong Earthquakes In The Western Sichuan Province And Its Adjacent Regions. Seismology and Geology, 3, 446-461, doi: 10.3969/j.issn.0253-4967.2005.03.010.

28. Zhan, J., Chen, J., Zhang, W., Han, X., Sun, X.Bao, Y. 2018. Mass movements along a rapidly uplifting river valley: an example from the upper Jinsha River, southeast margin of the Tibetan Plateau. Environmental Earth Sciences, 77, doi: 10.1007/s12665-018-7825-4.

29. Zhang, W., Li, H.-Z., Chen, J.-p., Zhang, C., Xu, L.-m.Sang, W.-f. 2011a. Comprehensive hazard assessment and protection of debris flows along Jinsha River close to the Wudongde dam site in China. Natural Hazards, 58, 459-477, doi: 10.1007/s11069-010-9680-9.

30. Zhang, Y., Zhao, X., Lan, H.Xiong, T. 2011b. A Pleistocene landslide-dammed lake, Jinsha River, Yunnan, China. Quaternary International, 233, 72-80, doi: 10.1016/j.quaint.2010.10.020.

\section{Figures}




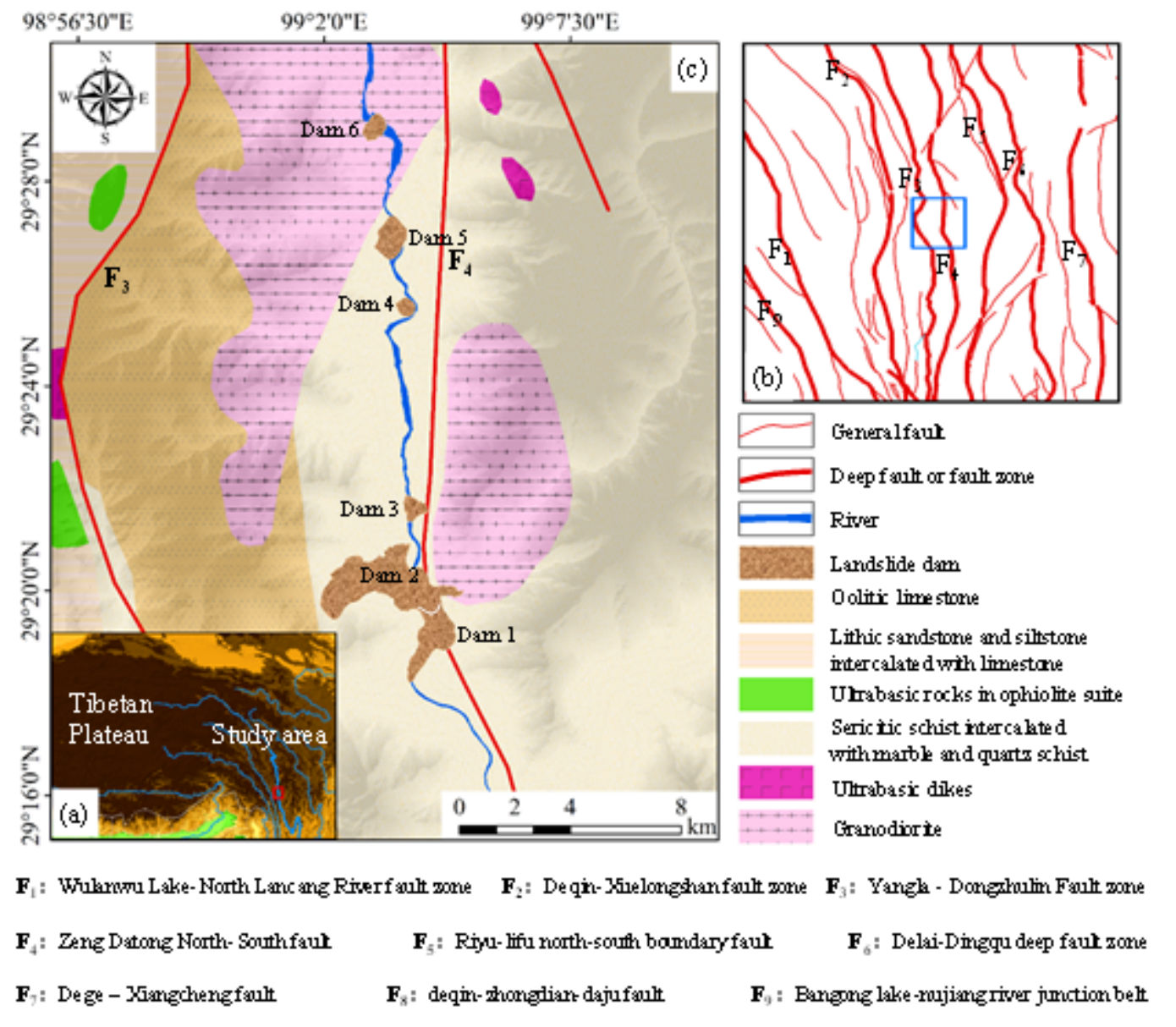

\section{Figure 1}

Map showing the locations and regional geologic settings (a) location of study area, (b) tectonic outline map (According to 1:1000000 geological map) (c) regional geological map (According to 1:1000000 geological map) 


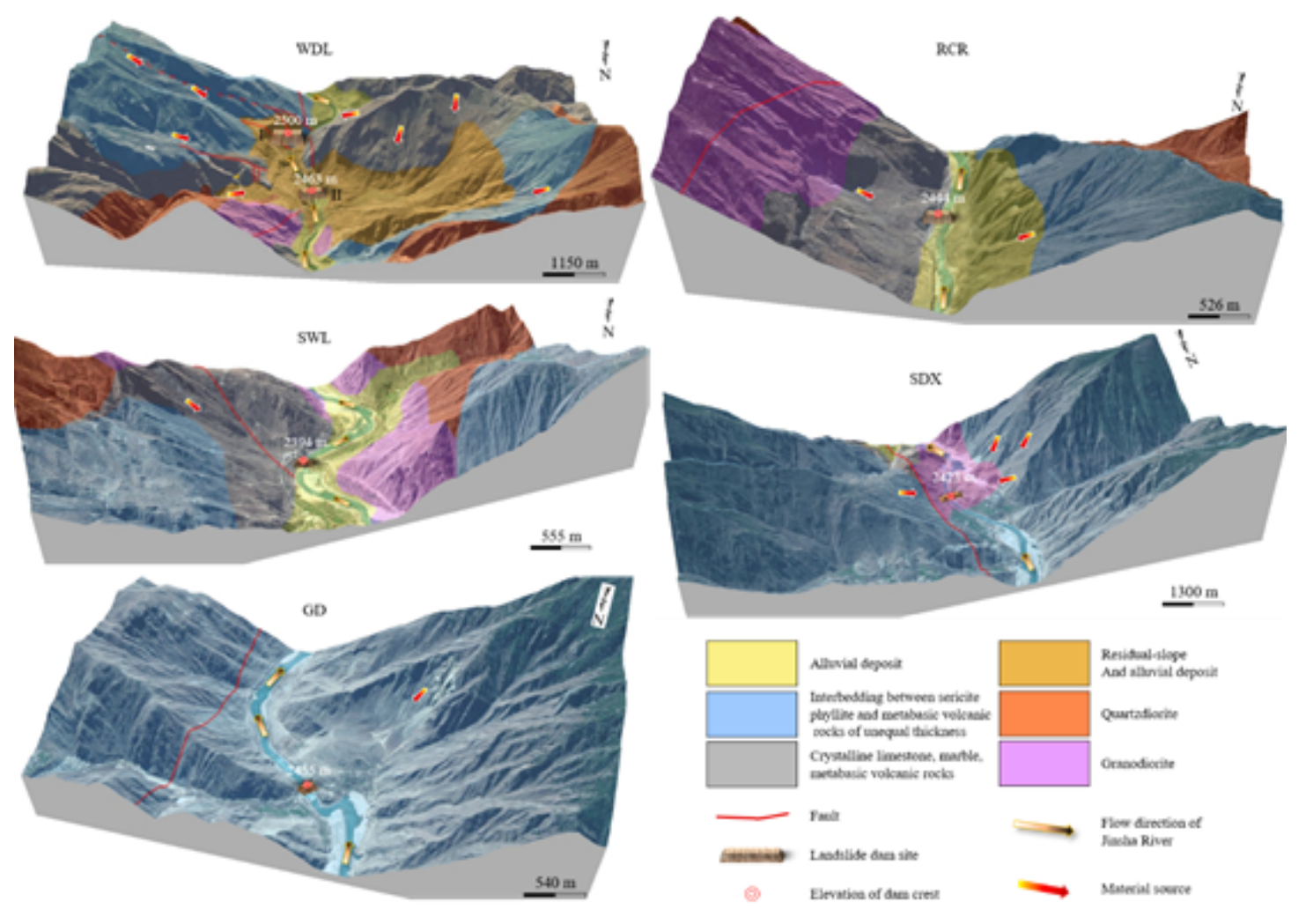

Figure 2

Map showing the Specific geological settings of the dam site. Note: Due to the limitation of data collection, picture WDL, RCR and SWL were generated according to 1:50000 geological map; Picture SDX and GD were generated according to 1:200000 geological map. 


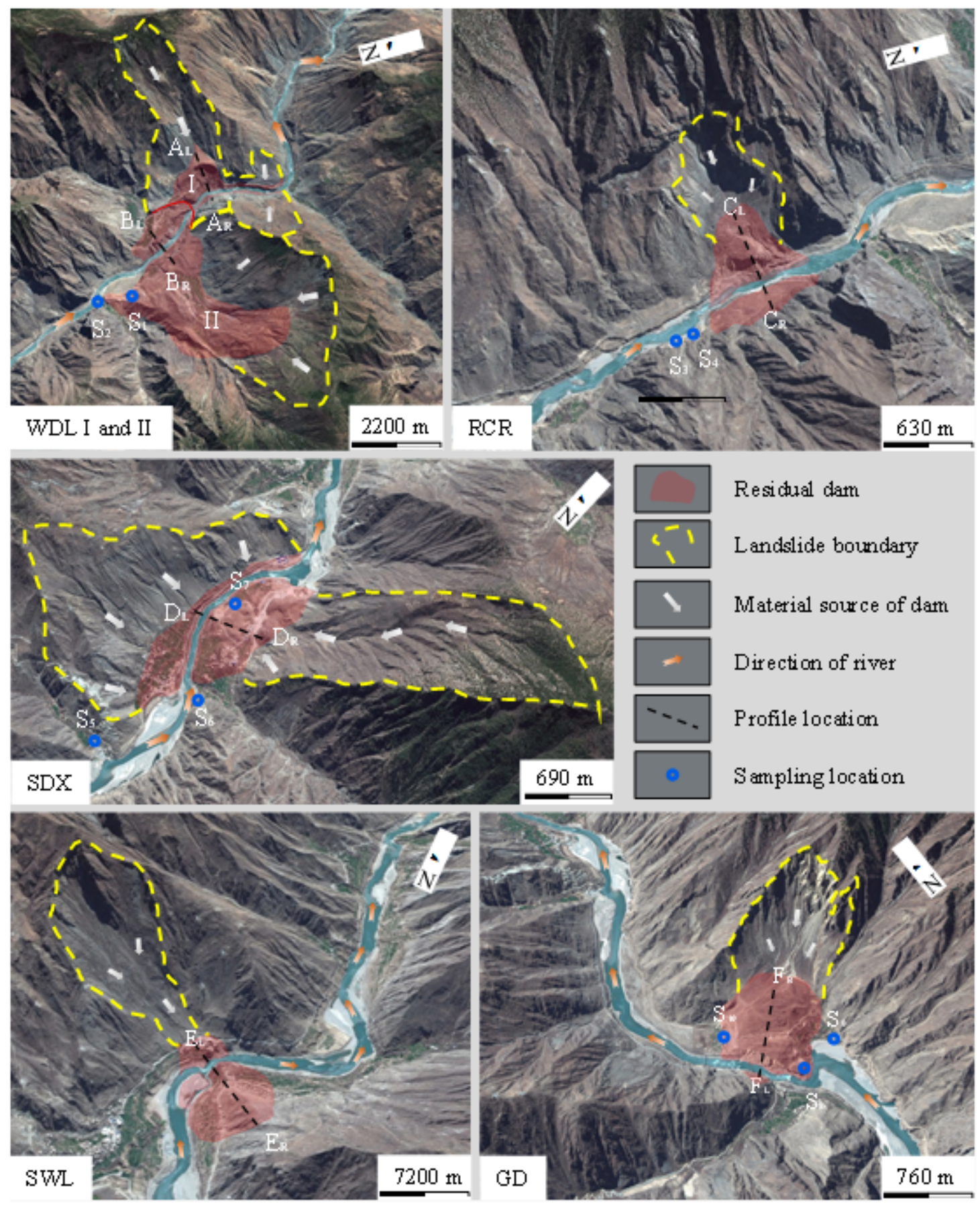

Figure 3

Remote sensing map of river blocking event 


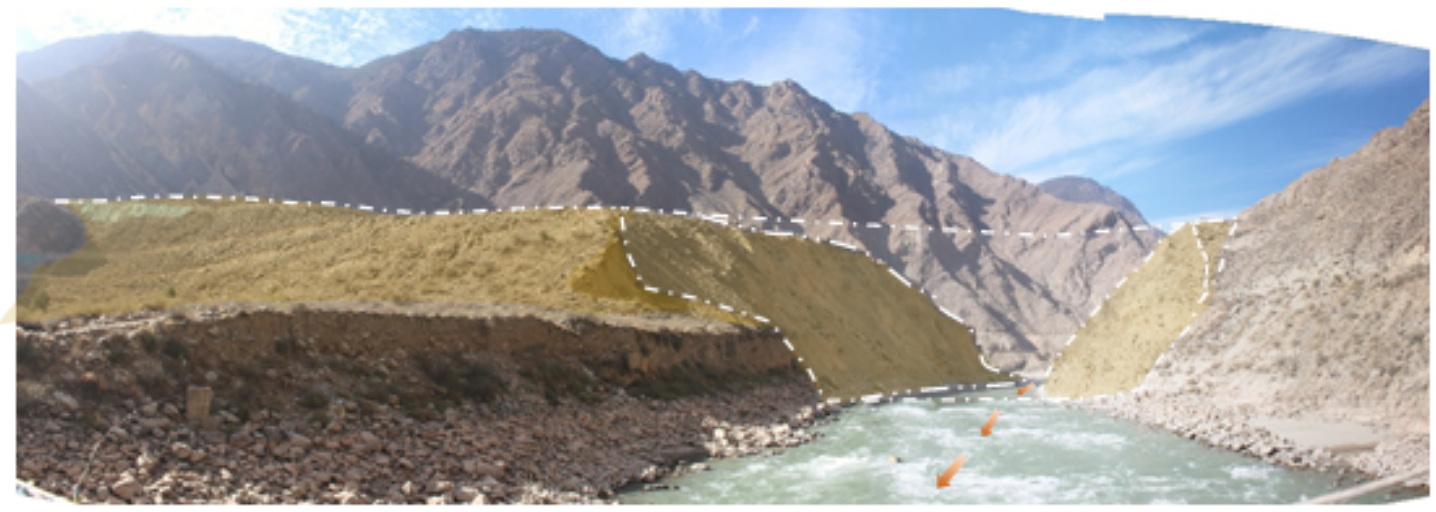

\section{Figure 4}

Geometry of GD landslide dam

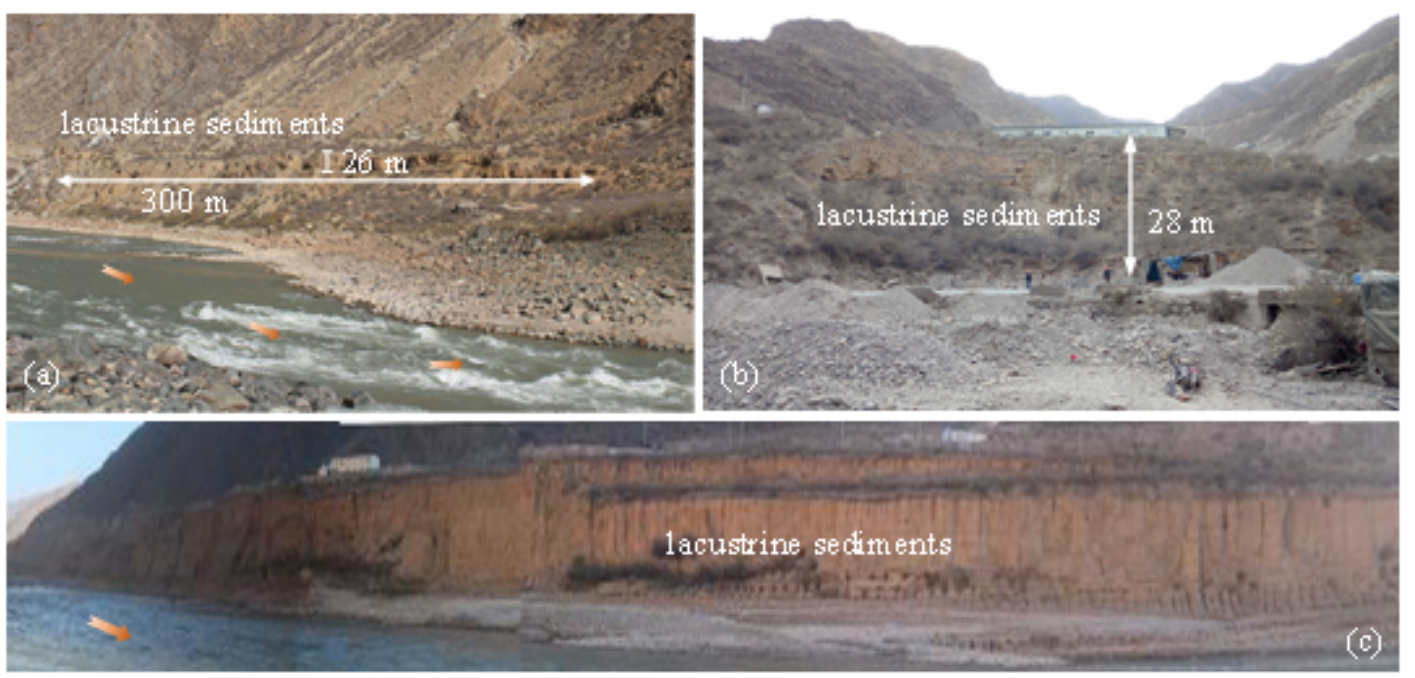

\section{Figure 5}

Lake sediments formed in dammed lakes. (a) in WDL-RCR reach; (b) in WDL-RCR reach; (c) in RCR-SWL reach 

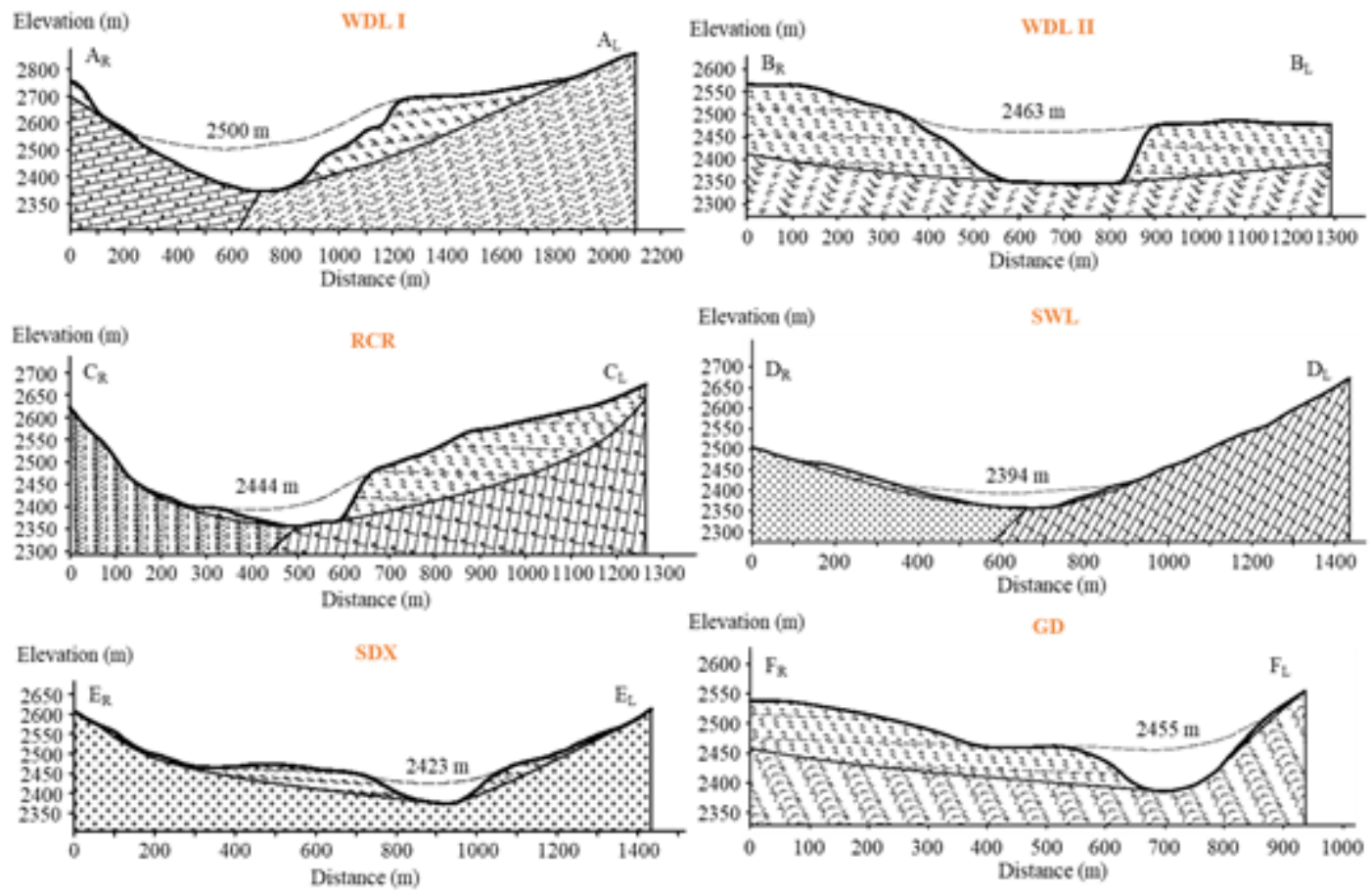

Residualdam $\square$ Crystalline limestone 2423 S peculating the shape of dam top and the elevation of damcrest

Gramodionite $\square$ Sericite phyllite $\square$ The current surface morphological line and lithologic bound aries

\section{Figure 6}

Speculated profile of each dam

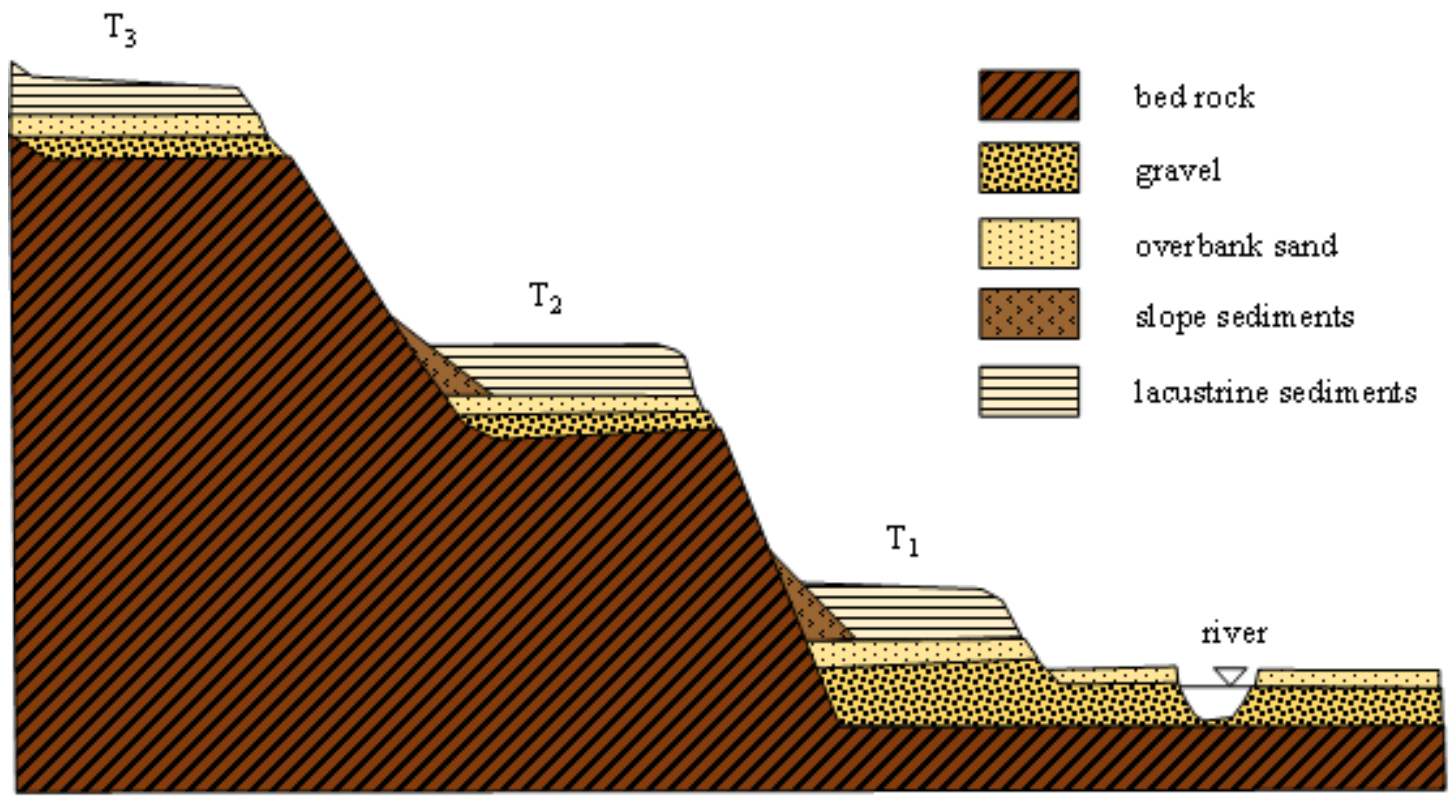

\section{Figure 7}




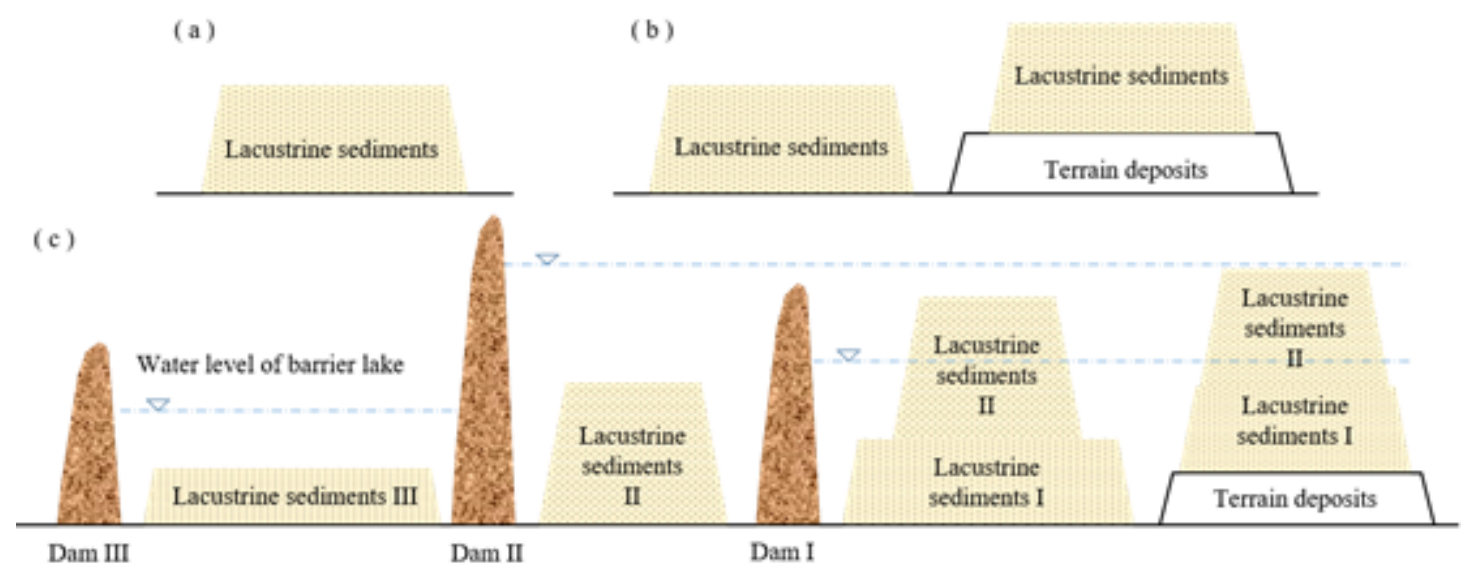

Figure 8

Diagram of the relationship between lacustrine sediments

Dating(a)

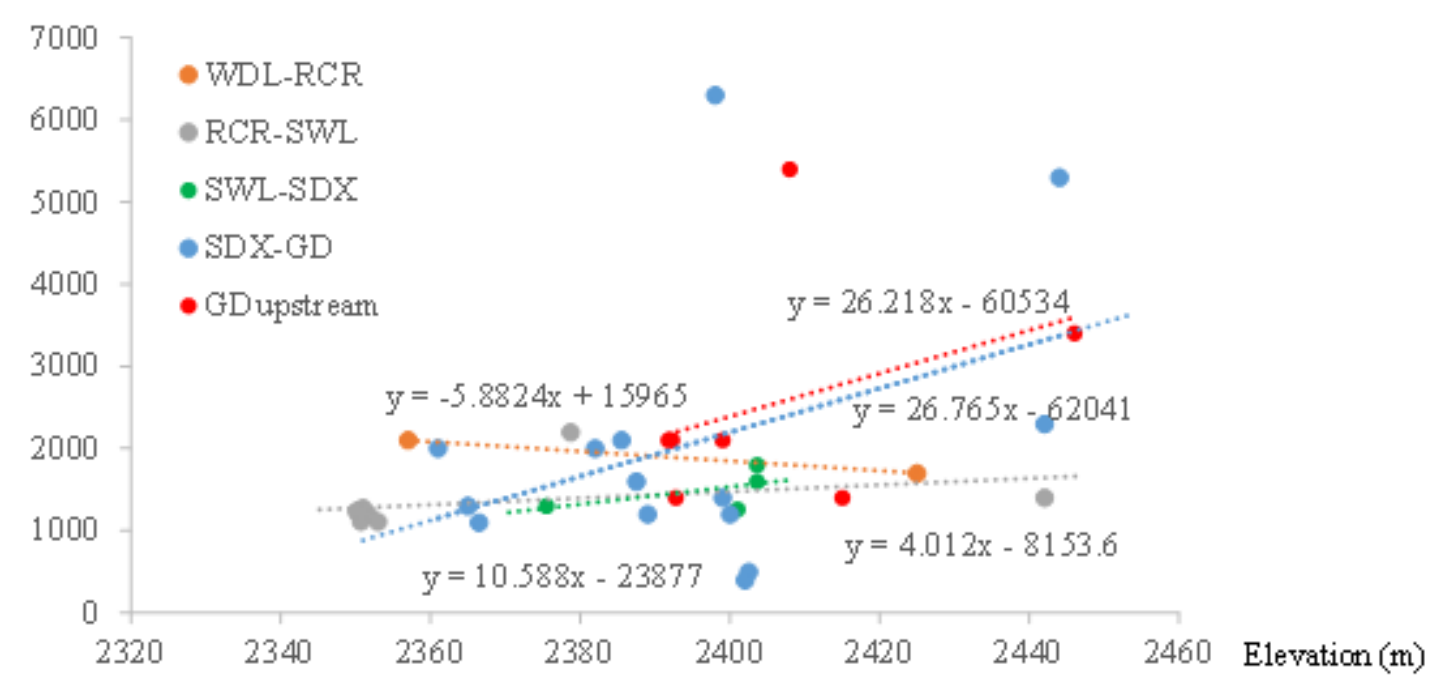

Figure 9

Unprocessed dating data 


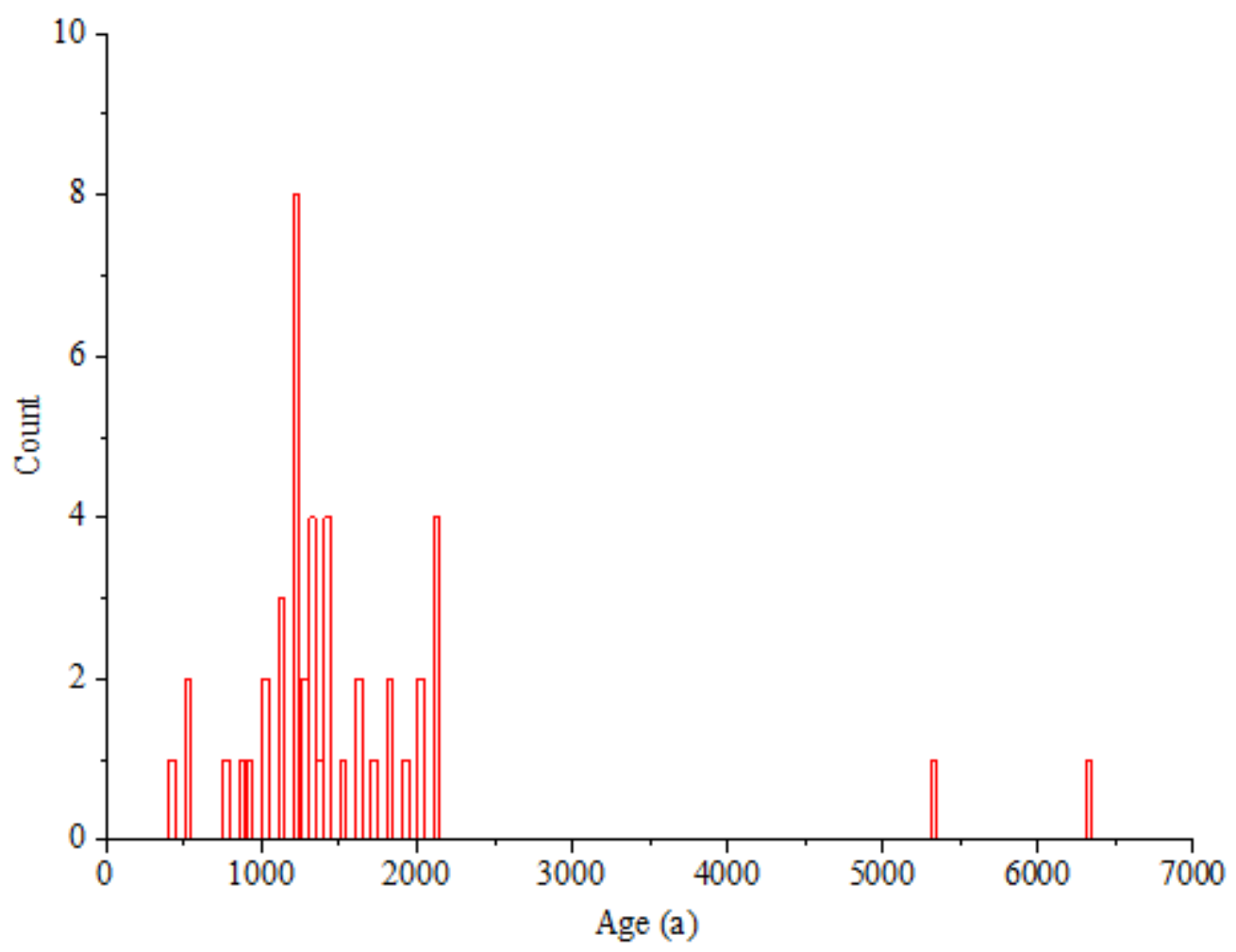

Figure 10

Frequency histogram of dating data

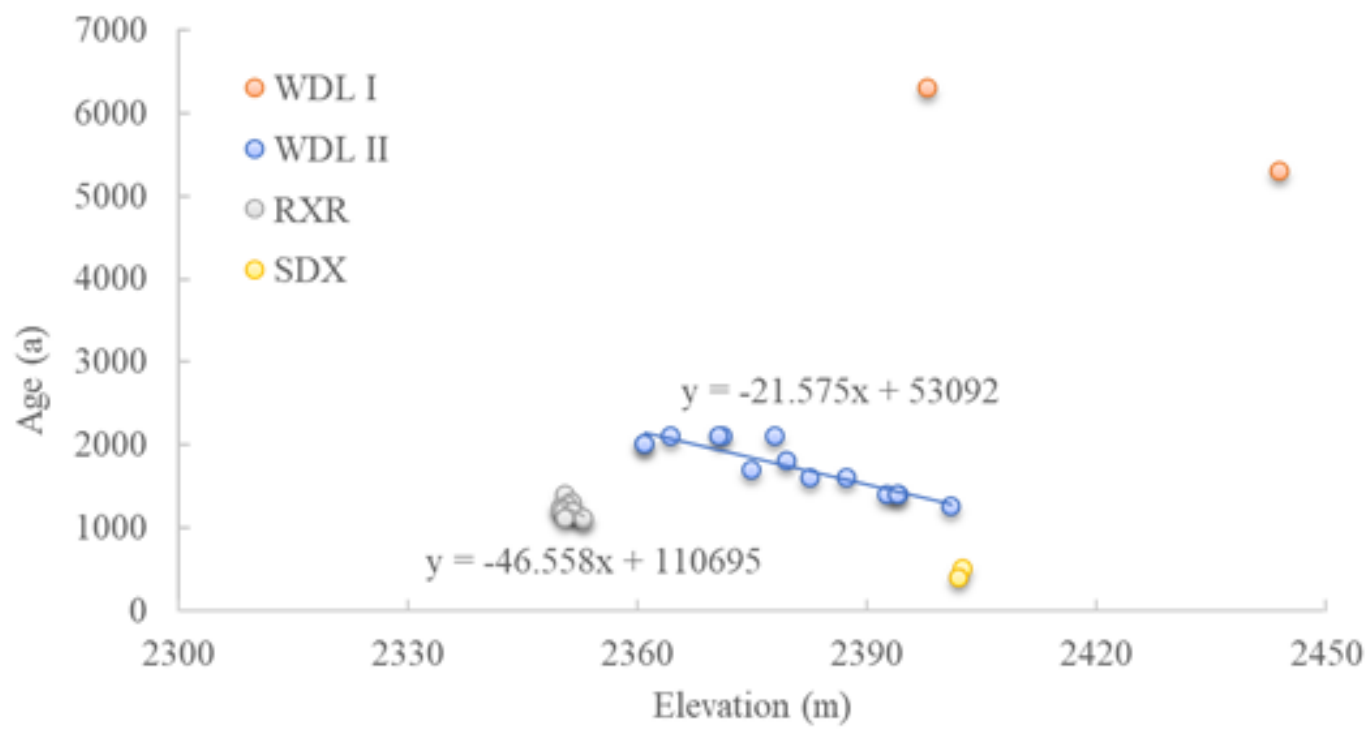

Figure 11

Grouping results of post-processing dating data 


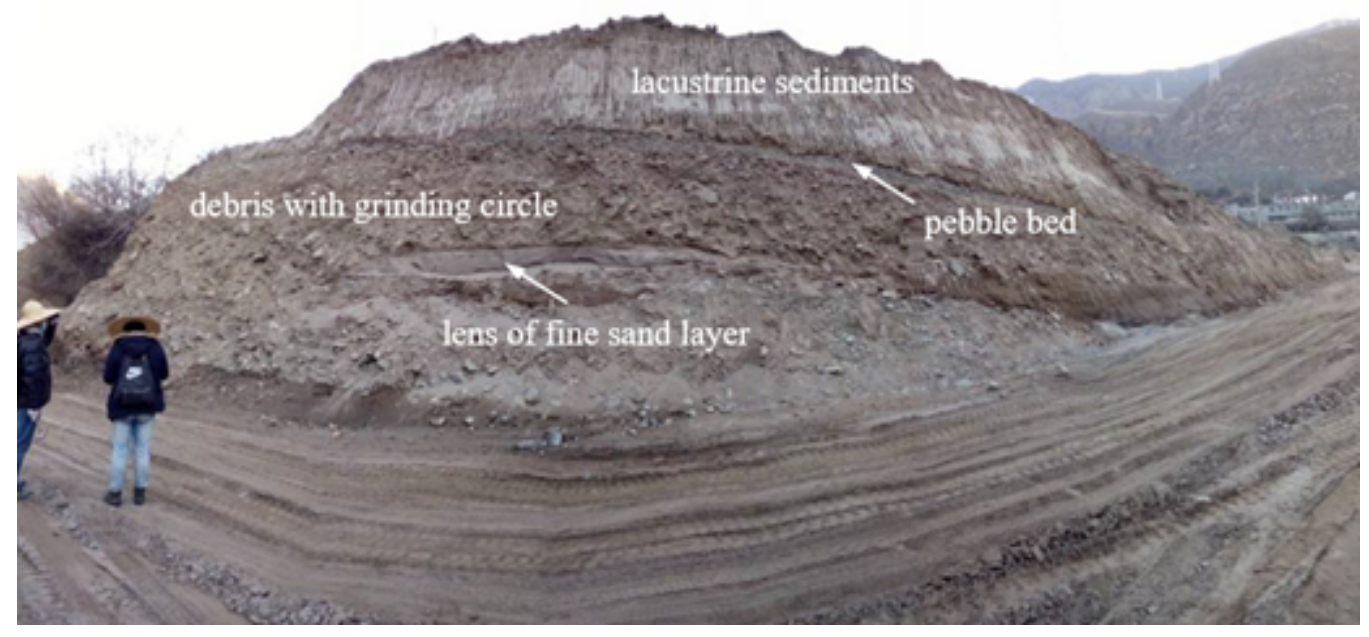

Figure 12

Stratification phenomenon in SWL-SDX reach
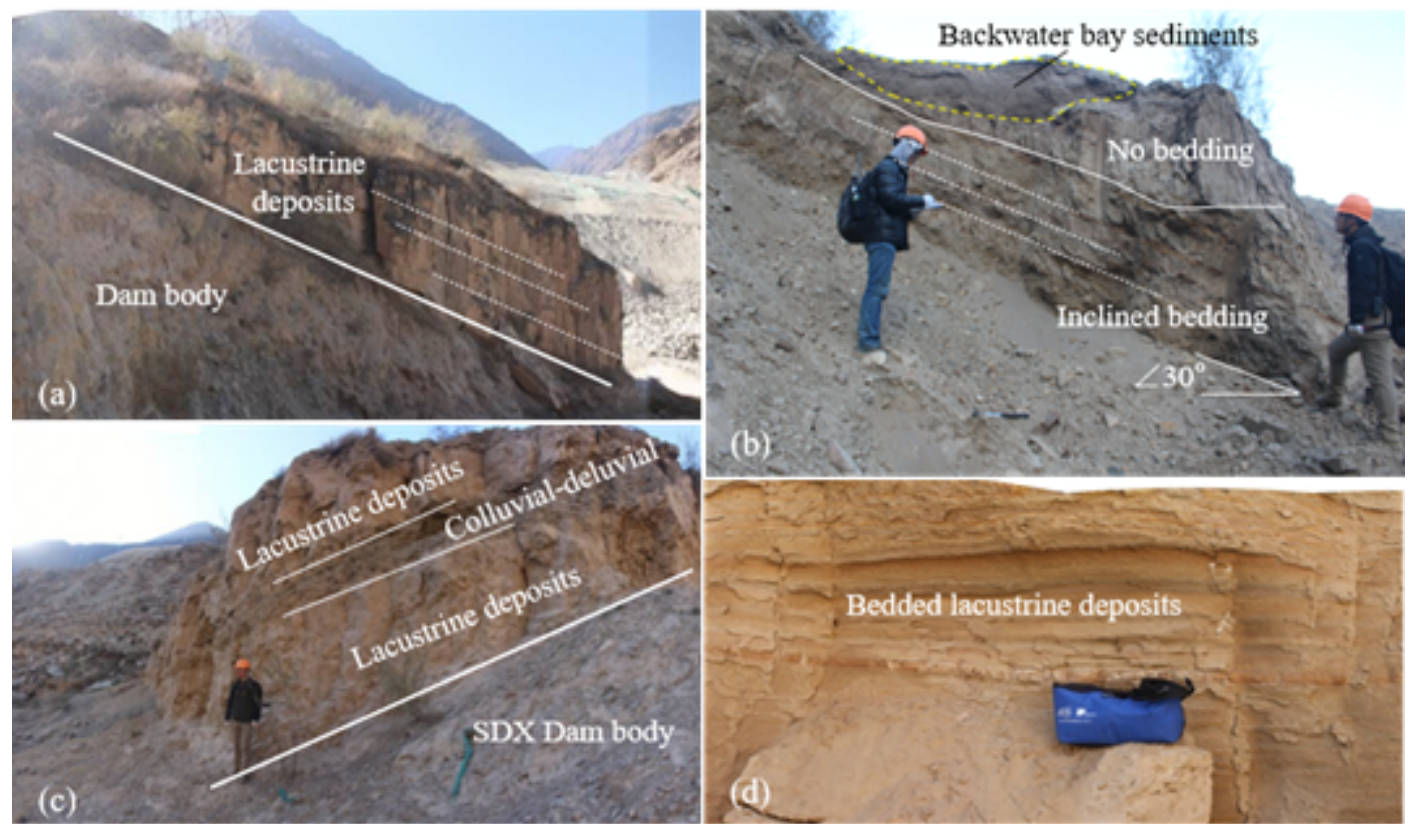

(b)
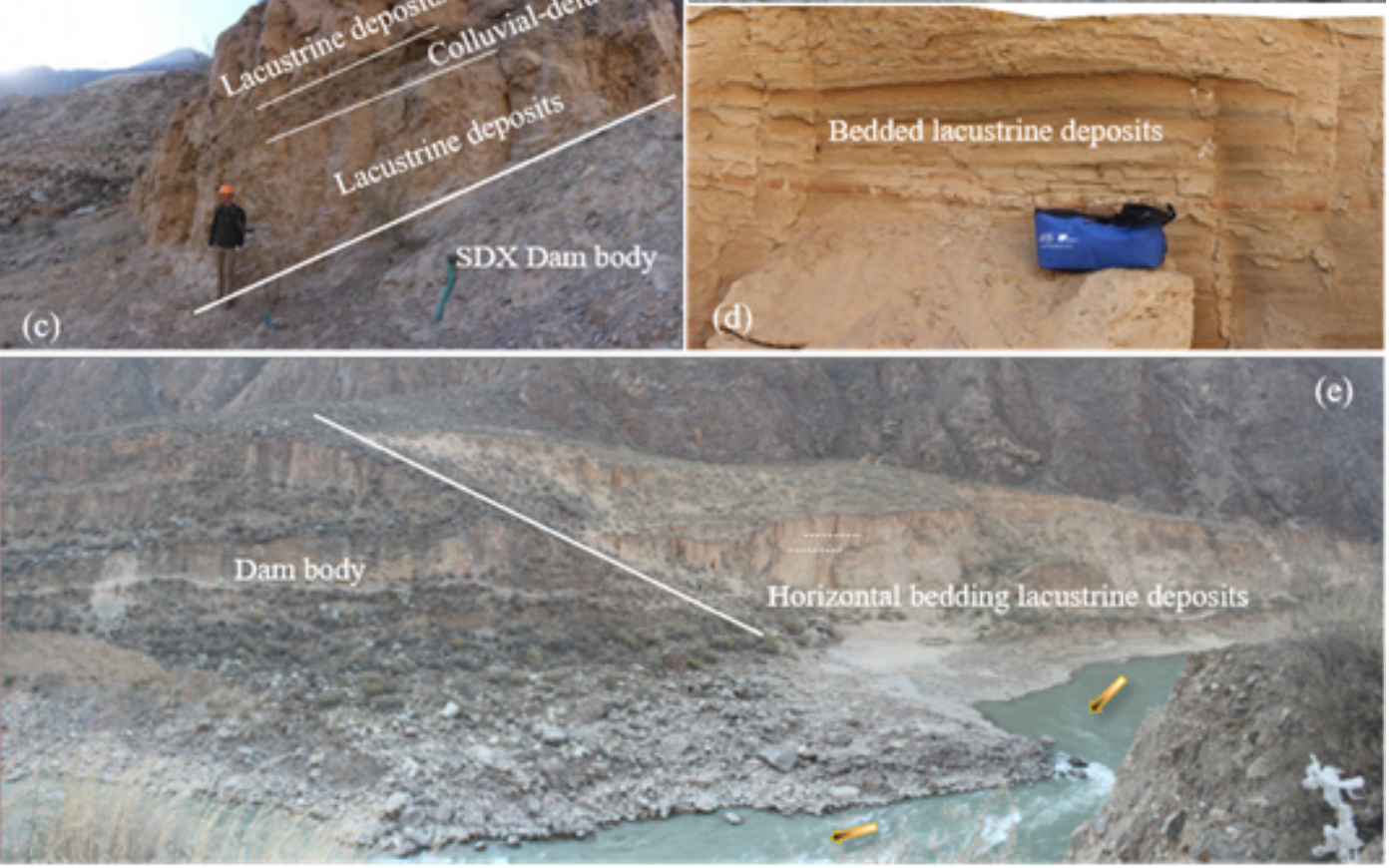
Figure 13

Typical geological phenomena. (a) Inclined lacustrine sedimentary layer on SDX dam body upstream; (b) Horizontal sedimentary layer covers inclined sedimentary layer phenomenon on GD dam body (c) Inclined lacustrine sedimentary layer on SDX dam body downstream; (d) Horizontally stratified lacustrine sediments in WDLII-RCR section; (e) Horizontally bedding lacustrine deposits layer on RCR dam body upstream

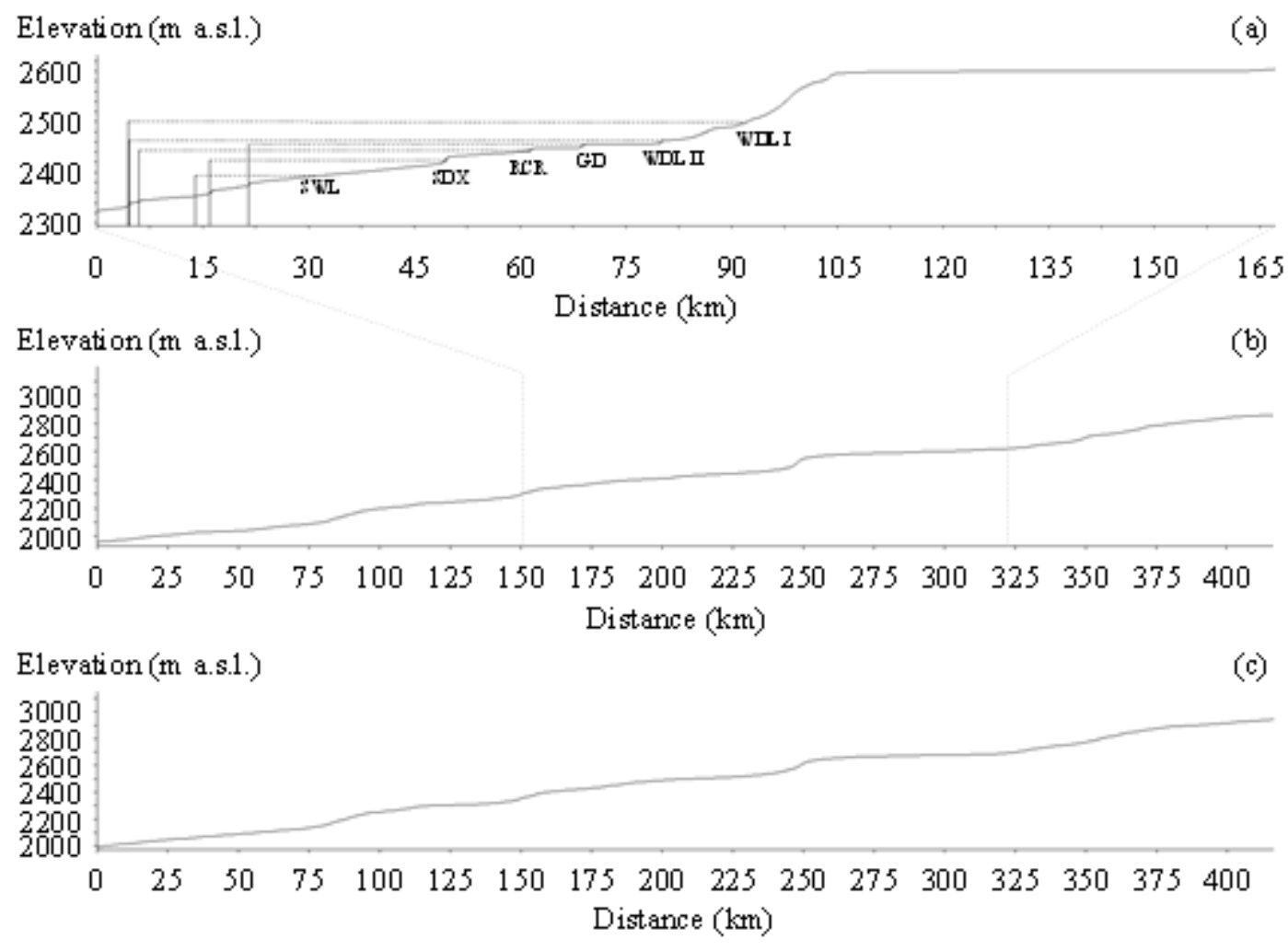

\section{Figure 14}

Fluvial response to River blocking dam. (a) is generated from ALOS $12.5 \mathrm{~m}$ DEM. (b) is generated from ALOS $12.5 \mathrm{~m}$ DEM in order to determine the scope of (a). (c) is generated from GDEMV2 30M as the control group of (b). 

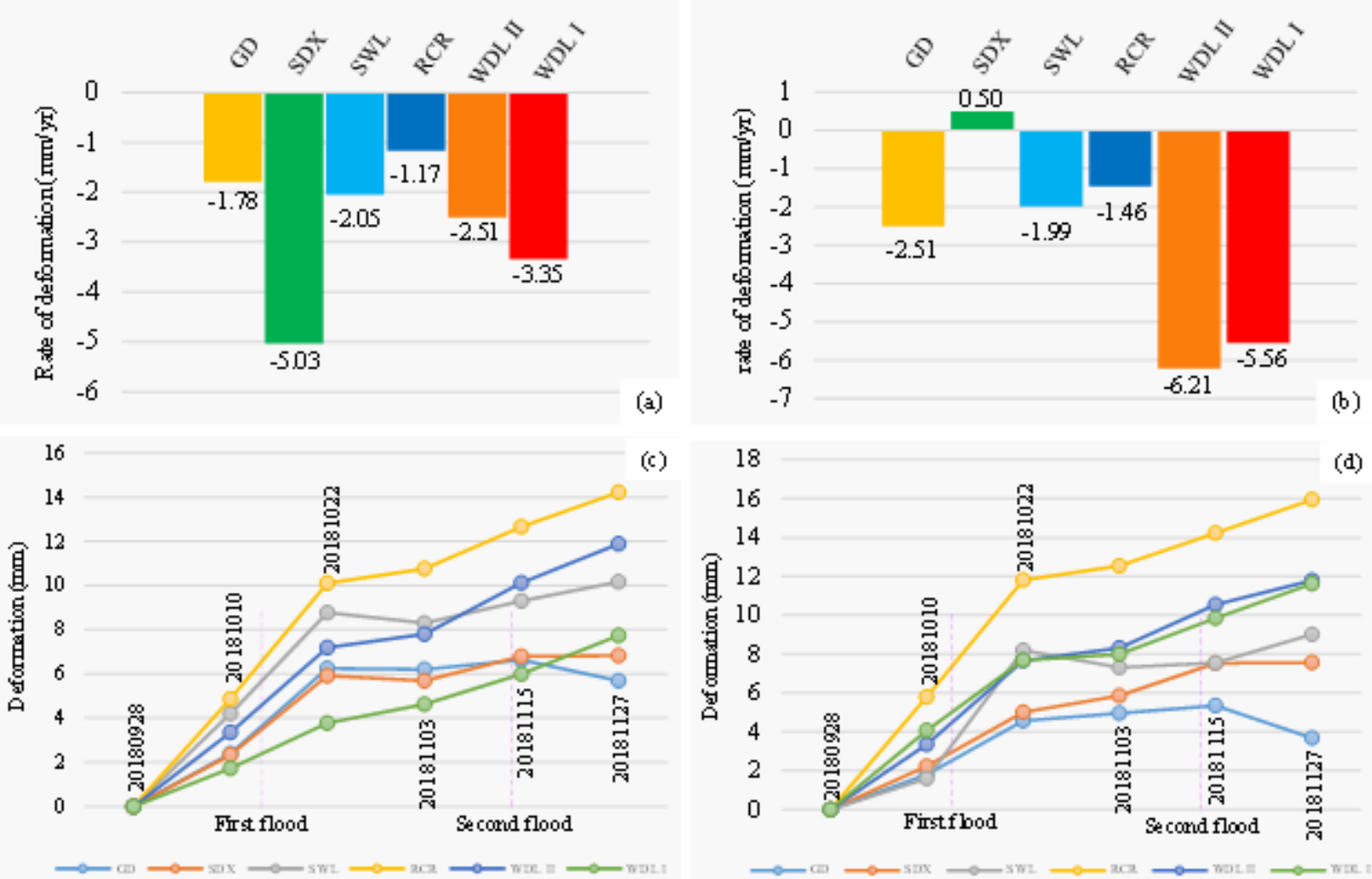

Figure 15

the surface deformation of the residual dam body. (a)the average deformation rate of the whole dam body; (b) the average deformation rate of part of the whole area along the river; (c) the response to the flood from Baige barrier lake of from both the whole dam body; (d) the response to the flood from Baige barrier lake of part of the whole area along the river 


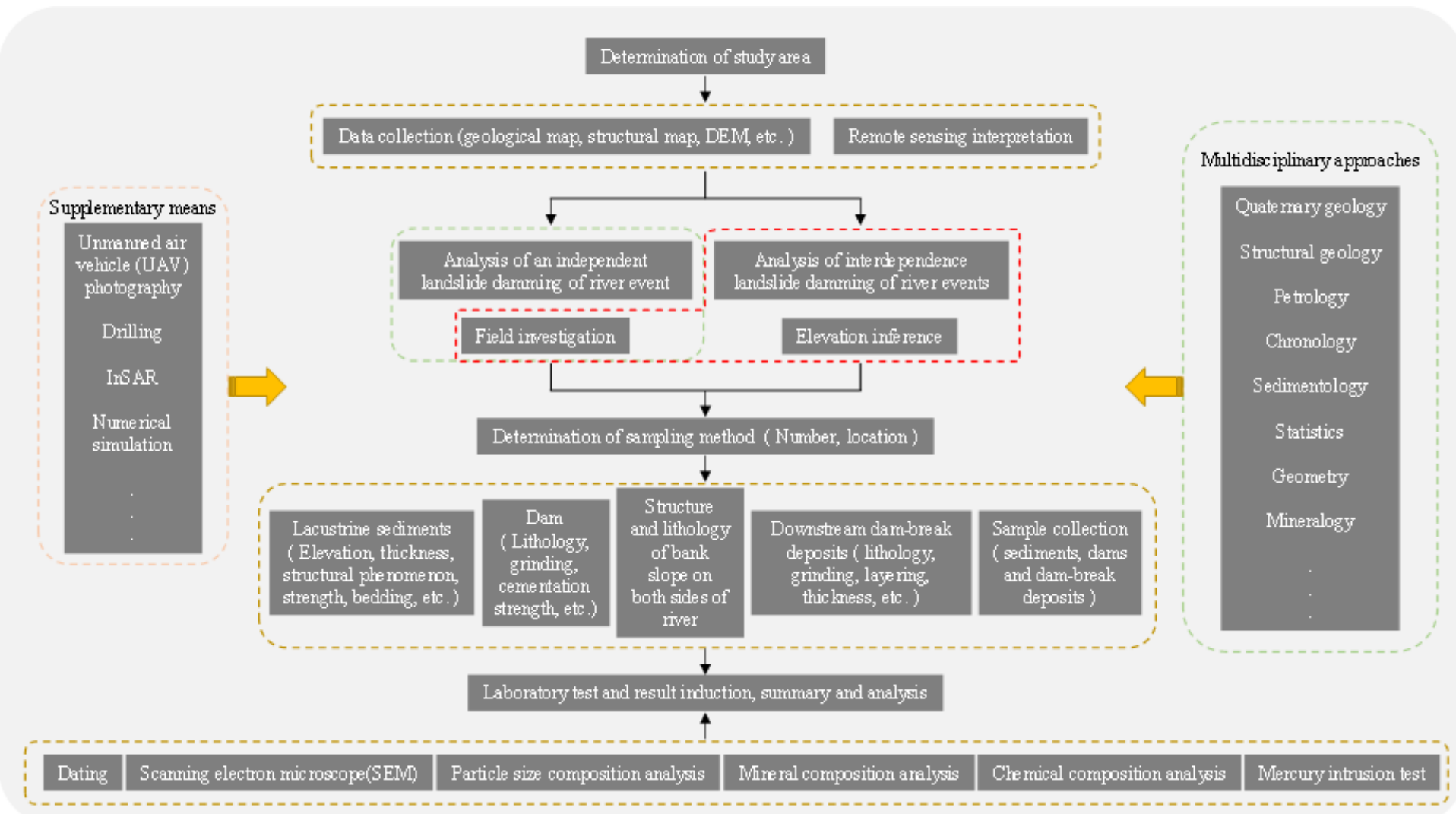

Figure 16

The general flow chart of studying the river blocking event 